\title{
The Silica Content of some Natural Waters and of Culture Media.
}

\author{
$\mathrm{By}$ \\ W. R. G. Atkins, O.B.E., Sc.D., F.I.C. \\ Head of the Department of General Physiology at the Plymouth Laboratory.
}

WHEN studying the seasonal changes in the algal plankton in relation to the supply of the constituents necessary for their growth, one is led to seek the source of the silica used to form the valves of the diatoms and to consider whether lack of silica might be a factor limiting their multiplication.

Since water is collected and stored in glass vessels it is also necessary. to consider how far the latter act as sources of silica which may lead to erroneous results, both in analytical examination of samples and in culture experiments.

Accordingly, the silicate, reckoned as $\mathrm{SiO}_{2}$ was estimated in natural waters as shown in Table 1 (page 152). The "chloride" bottles mentioned are the usual ones as supplied for sampling sea-water. They are of green glass with porcelain stopper and rubber ring, closed with a metal spring clamp, and are of about 170 c.c. capacity. The Winchester quart bottles are of light green glass.

\section{SILICA CONTENT OF FRESH-WATER.}

The figures in Table 1 do not appear to indicate any appreciable rate of solution of the silicate of the bottles, for the lowest value, 0.48 for Maryfield pond, was obtained on a sample which had stood for two months in the bottle. The difference between this minimum value and the ones which come before and after it seems remarkable, and on turning up some quantitative estimations of the algal plankton it was seen that whereas on 15th of April the pond contained roughly 15,000 diatoms per cubic centimetre, on 24th there were $27-32,000$ and a Chlamydomonas surface scum in parts. On May 6th diatoms had greatly decreased, being apparently under 1000 per c.c., and an Euglena scum was starting to develop. This increase in diatoms, corresponding with a decrease in 
silica, suggests an explanation of the low value for the latter. In view, however, of the fact that the method, as used in the estimation in question, is incapable of detecting much less than $0.2 \mathrm{mgrm}$. of $\mathrm{SiO}_{2}$, the observation needs confirmation.

The highest values for silica, $6 \cdot 25$ mgrms, is given by the Basingstoke town supply, which comes from deep wells in chalk, whereas the Plymouth

TABLE 1.

Fresh-WATER.

Source of Sample.

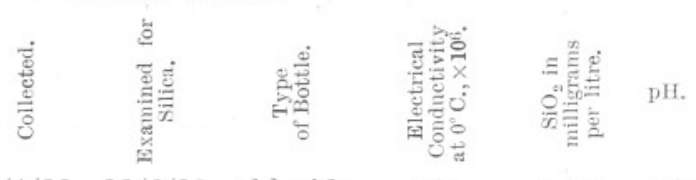

$\begin{array}{llllll}\text { Maryfield quarry pond } 15 / 4 / 23 & 22 / 6 / 23 & \text { chloride } & 161 & 0 \cdot 76 & 8 \cdot 7\end{array}$

\begin{tabular}{|c|c|c|c|c|c|c|c|}
\hline , &, & $24 / 4$ & , & , & 170 & $0 \cdot 48$ & $8 \cdot 6$ \\
\hline " &, & $6 / 5$ & , & , : & 182 & $0 \cdot 68$ & $8 \cdot 6$ \\
\hline , & , & $2 / 6$ & , &, & 190 & $1 \cdot 04$ & $8 \cdot 5$ \\
\hline , & , & $17 / 6$ & $20 / 6$ & ," & 200 & $1 \cdot 30$ & $8 \cdot 2$ \\
\hline , & , & $24 / 6$ & $25 / 6$ & , & 192 & $0 \cdot 94$ & $8 \cdot 2$ \\
\hline ", & , & $30 / 6$ & $2 / 7$ & , & 196 & $0 \cdot 92$ & $8 \cdot 0$ \\
\hline Staddon reserv & voir & $3 / 4$ & $22 / 6$ & ", & 244 & $4 \cdot 2 *$ & $8 \cdot 4$ \\
\hline, & & $1 / 5$ & $22 / 6$ & , & 204 & $4 \cdot 0^{*}$ & $8 \cdot 3$ \\
\hline, & (inlet) & $1 / 5$ & $22 / 6$ & , & 270 & $2 \cdot 88$ & - \\
\hline$"$, & (inlet) & $23 / 6$ & $23 / 6$ & , & 270 & $3 \cdot 30$ & - \\
\hline, & & $23 / 6$ & $23 / 6$ & , & 238 & $2 \cdot 4 \dagger$ & $7 \cdot 95$ \\
\hline , & & $29 / 6$ & $29 / 6$ & , & 208 & $1 \cdot 76$ & $8 \cdot 6$ \\
\hline , & (inlet) & $29 / 6$ & $29 / 6$ & , & 270 & $3 \cdot 28$ & $6 \cdot 65$ \\
\hline, & (inlet) & $26 / 7$ & $1 / 8$ & , & 287 & $6 \cdot 25$ & $6 \cdot 65$ \\
\hline, & & $26 / 7$ & $1 / 8$ & , & 204 & $3 \cdot 45$ & $8 \cdot 7$ \\
\hline Basingstoke ta] & & $23 / 6$ & $25 / 6$ & ,, & 270 & $6 \cdot 25$ & $7 \cdot 2$ \\
\hline Maryfield tap & & $24 / 6$ & $25 / 6$ & , & 270 & $4 \cdot 44$ & $7 \cdot 2$ \\
\hline Plymouth tap & & $21 / 6$ & $21 / 6$ & From pipe & 25 & $3 \cdot 33$ & $6 \cdot 4$ \\
\hline
\end{tabular}

tap from Burrator Reservoir on Dartmoor, a granite area, has only about half the quantity, $3 \cdot 33$ mgrms. The latter, however, constitutes a relatively higher proportion of the total solids, as shown by the electrical conductivity measurements. Maryfield tap supply comes from a Staddon Grits catchment area in the Lower Devonian Series, on which the Staddon

* Water had brownish tint. $\quad$ Slight tint. 
reservoir-a cemented tank fed in dry weather only by an inlet pipeis also situated. This in the July drought equalled the high Basingstoke value. The Maryfield quarry pond lies on Upper Devonian Slate. It appears that some cause must be active in removing silica from the water of the ponds, which show lower values than the spring waters.

It is to be noted that the tap water at $\mathrm{pH} 7 \cdot 2$ is in each case rich in calcium salts, and becomes more alkaline as excess of carbon dioxide passes off into the air ; thus one would expect it to be a better solvent for silica as its $\mathrm{pH}$ value rises, hence the lesser content of silica in the ponds is not due to a chemical precipitation occasioned by increasing alkalinity. This again points to the removal of silica by a biological agency, for example, by diatoms.

In view of the work of Thresh (1922) upon the importance of the silica content of town supply water in reducing the action of oxygen upon lead, the action of diatoms becomes of increased interest, especially as their great abundance at certain periods might cause seasonal changes in the plumbo-solvency of water supplies. Thresh found that the water of Loch Katrine with only $0 \cdot 1 \mathrm{mgrm}$. per litre $\mathrm{SiO}_{2}$ had the greatest action upon lead of any source examined.

\section{SILICA CONTENT OF SALT-WATER.}

The electrical conductivity and $\mathrm{pH}$ values have been omitted from Table 2 (page 154), as the sea water is of almost identical salinity at all the stations examined and the $\mathrm{pH}$ value was at $8 \cdot 1-8 \cdot 2$.

The analyses appear to indicate a decrease in silica content as summer is approached, and such a decrease must occur almost certainly in view of the minute amount available. The figures given do not, however, prove this, on account of the possible solution of traces from the glass. Assuming that the value $0 \cdot 2 \mathrm{mgrm}$. for June 25 th is correct, the Winchester filled in December appears to have been enriched with $\mathrm{SiO}_{2}$ by $0.2 \mathrm{mgrm}$. per litre per month, and the May Winchester by 0.35 for one hot month.

On the other hand, there is no evidence that one month in chloride bottles has resulted in any silica going into solution when stored in the dark, and over a seven-month period the amount dissolved cannot have exceeded $0.06 \mathrm{mgrm}$. per litre per month, even were the water no richer in silica in winter than in summer. It seems, therefore, that $t$ is quite permissible to use chloride bottles to convey sea water from the hydrographic stations to the Laboratory for immediate analysis, namely, for storage of up to five days, for this could not increase the silica content by more than 0.01 mgrm. per litre. 


\section{TABLE 2.}

Salt-water.

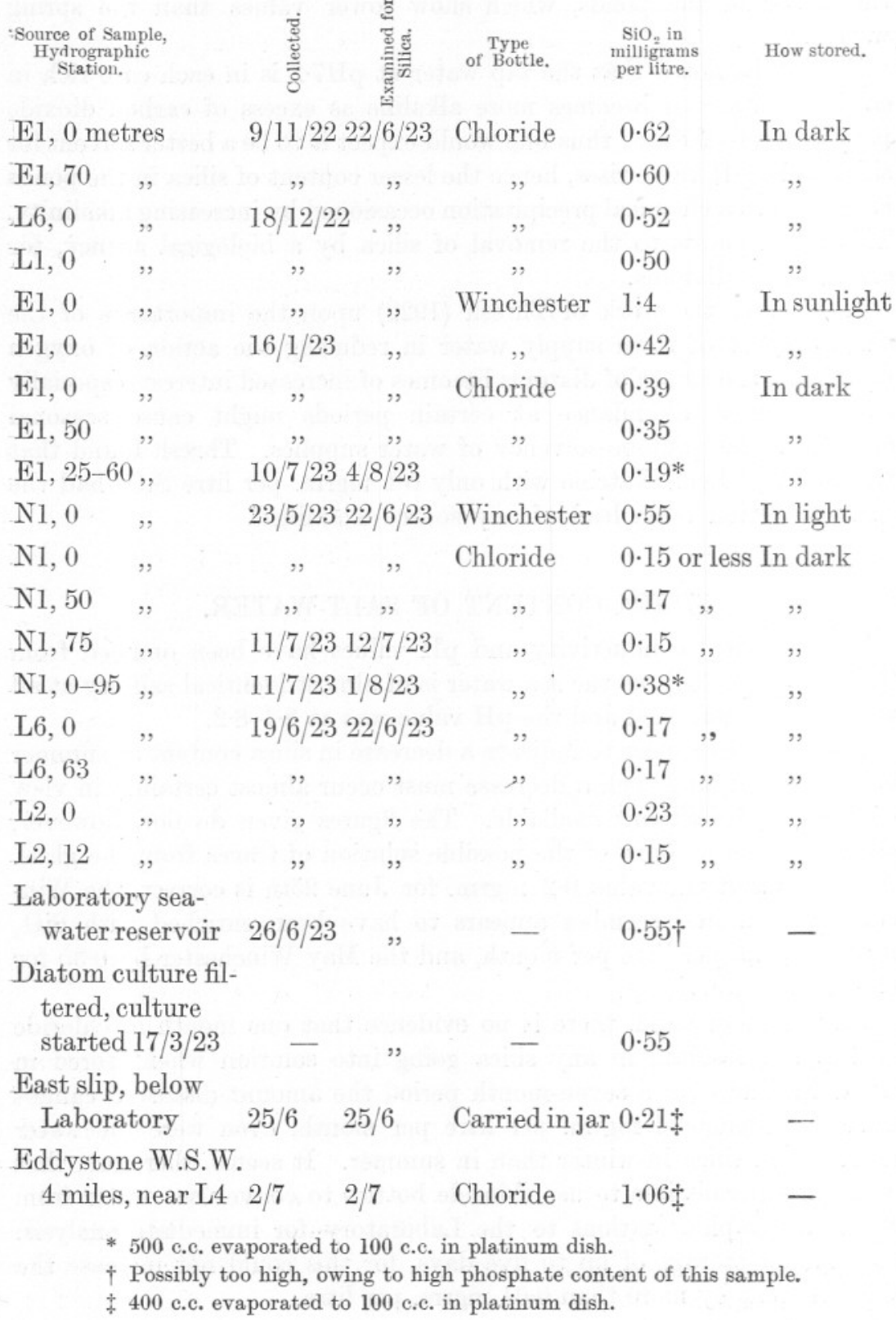


It appears that the value $1.06 \mathrm{mgrm}$. for July 2 nd is abnormally high, and may have resulted from the solution of particles of some source of silica during the evaporation, possibly of diatoms. That some silica has gone into solution during the evaporation is also indicated by the values for Station N1 on July 11th. Here a determination on the untreated 75-metre sample showed 0.15 mgrm. or under, whereas on evaporating 500 c.c., made up of portions of samples from surface to bottom, $0.38 \mathrm{mgrm}$ was obtained. In this and the corresponding E1 sample 500 c.c., made up of portions of samples from surface to bottom, the salt incrustation in the platinum dish was dissolved, and the silica retained, if any, added to that in the salt water. Thus for N1 the latter amounted to $0.132 \mathrm{mgrm}$, and the incrustation contained $0.060 \mathrm{mgrm}$. No silica could, however, be detected in the incrustation of the E1 sample.

Brandt (1920) has recorded a seasonal change in the water of the Baltic as regards silica, 900 mgrms. per cubic metre (or $0.9 \mathrm{mgrm}$. per litre) in February having diminished to 600 mgrms. in May. This was followed by a rise in June. Bottom water was somewhat richer, 1150 mgrms. having been found in February. As the Baltic is altogether surrounded by land it seems reasonable that its silica content should be somewhat higher than that of the English Channel, for the fresh waters examined by the writer are all richer in silica than is the sea. Furthermore, it was found that by shaking up one part of air-dried soil (which passed a sieve of one hundred meshes to the inch and gave a reaction of $\mathrm{pH} 7 \cdot 8$ ) with five of water, after eleven days the resulting solution contained $13 \cdot 2 \mathrm{mgrm}$. of silica per litre.

\section{ACTION OF DISTILLED AND OF SALT-WATER UPON GLASS.}

In order to test the action of water upon glass vessels such as were, or might be, used for diatom cultures, the following were tested by filling them about half full of distilled water and leaving them for two hours on a boiling-water bath, after which they stood for a day. It was then found that a small flask of English glass, used by Dr. E. J. Allen for diatom cultures, a litre flask of English $\mathrm{R}$ glass, also used for cultures, a Moncrieff conical flask, 350 c.c., a Jena litre flask, and a Kavalier S, 500 c.c. conical flask were so insoluble that the distilled water showed a conductivity of less than $0 \cdot 000,01$ at $0^{\circ} \mathrm{C}$., the lowest measurable with the cell used. On further testing the Jena and Kavalier vessels with a cell of lesser resistance the Jena glass showed the limiting value $\cdot 0 \cdot 000,001$ and the Kavalier $0 \cdot 000,002$. It may be added that the purest water obtainable in contact with atmospheric carbon dioxide has a 
conductivity of $0 \cdot 000,000,7$, and Lehfeldt (1908) gives $0 \cdot 000,005$ as the maximum allowable in water used for conductivity work, though $0 \cdot 000,001$ is usually required for research work. Colorimetric measurements of hydrogen ion concentration also showed that these vessels had maintained the distilled water at below $\mathrm{pH} 6$, so they may all be considered as highly resistant to the action of pure water. Before applying the foregoing tests they were all proved to contain less than $0 \cdot 2 \mathrm{mgrms}$. per litre of $\mathrm{SiO}_{2}$, which is the limit for the method without concentrating the water. Subsequently a Kavalier B conical flask, an unmarked conical flask, and a Swedish Reijmyre special glass beaker were similarly shown to contain no measurable amount of silica in solution, but they were not submitted to the other tests.

The vessels were then filled as before, and heated for three hours, but with sea-water instead of distilled water. The sea-water contained under $0 \cdot 2$ mgrms. per litre of $\mathrm{SiO}_{2}$ at the start, and after the treatment various amounts of silica from $1 \cdot 7$ up to $5 \cdot 7$ mgrms. per litre were found, the average for the eight vessels being $3 \cdot 7$ per litre. Since the vessels were of diverse shapes, unequal areas were exposed, so truly comparable results cannot be given. It seems accordingly that in time even these highly resistant glasses must give up to sea-water the small amounts of silica required in diatom cultures. This has been proved by Richter (1904), who showed that using vessels coated with paraffin wax, abundant diatom cultures could not be obtained. The culture medium used by Dr. E. J. Allen consists of sea-water enriched by Miquel's solution (1910), and then heated to boiling. The water of such a culture of Nitzschia closterium, which had multiplied to the extent of over three millions per cubic centimetre, was filtered through paper, and no diatoms were to be seen in the uncentrifuged filtrate. The latter was then found to contain 0.55 mgrms. per litre of $\mathrm{SiO}_{2}$ in solution, so it is evident that either during the boiling or subsequent standing, or during both together, a considerable amount of silica must have become available. The figure given may possibly be high, owing to phosphate in the solution also. It may be added that the boiling of sea-water increases its alkalinity up to $\mathrm{pH} 10$, and diatom cultures exposed to a good north light become nearly as alkaline, pH9.6 having been observed. As compared with distilled water at $\mathrm{pH} 6$, sea-water at $\mathrm{pH} 8$ contains one hundred times as great a concentration of hydroxyl ions, and at $\mathrm{pH} 10$ the concentration is again increased an hundredfold, namely, ten thousand times in all, so it is not surprising that silica should go into solution far more readily. than in distilled water.

As regards the sources of silica for diatom cultures the work of Coupin (1922) is of interest. He found that whereas Knop's solution made up with one per cent gelose gave no growth of Nitzschia linearis without. 
any form of silica, or with gelatinous silica or washed vitreous silica (Fontainebleau sand), yet a splendid growth was obtained when washed kaolin was sprinkled on the surface of the medium. Powdered feldspar also gave a good growth, part of this mineral being altered to kaolin. Pure clays were found to act like kaolin, but potassium and sodium silicates gave no growth or even killed the diatom, nor did powdered glass on the surface lead to any growth. The results were confirmed in celluloid dishes. Coupin concluded that diatoms obtain the silica they require from silicates of aluminium. Just prior to this Vernadsky (1922) had shown that a species of Nitzschia obtained from moist earth could grow well in cultures provided with kaolin, and could decompose clay with liberation of free aluminium hydroxide. Bacteria were also present in the cultures. Murray and Irvine (1891) had previously invoked the presence of particles of clay in sea-water as a source of the silica required by diatoms.

\section{METHOD OF ESTIMATION OF SILICA.}

The analyses recorded in this paper were carried out by the colorimetric method of Diénert and Wandenbulcke (1923). For this two reagents are required, a 10 per cent solution of ammonium molybdate, and a 50 per cent (by volume) solution of sulphuric acid. For each 100 c.c. of water to be tested 2 c.c. of molybdate and four drops of acid are added. A yellow colour develops, and reaches its maximum in less than ten minutes, after which it remains constant for some time. The directions given by Diénert and Wandenbulcke are to add four drops of acid to 50 c.c. On adding eight to 100 c.c. it was, however, found that a blue tint was apt to develop, which was difficult to match against picric acid, though the normal yellow tint could be matched exactly. This difficulty was at first overcome by adding a trace of methylene blue to the standard picric acid. Using 100 c.c. of distilled water, 2 c.c. of ammonium molybdate at $\mathrm{pH} 5 \cdot 3$, and eight drops of acid, the resulting mixture was found to be at $\mathrm{pH} 1 \cdot 6$, and in this a blue colour developed with the yellow. With twelve drops $\mathrm{pH} 1 \cdot 4$ was reached and with sixteen $\mathrm{pH} 1 \cdot 25$, the blue becoming increasingly stronger. However, by using only four drops of acid in sea-water a clear yellow was given at $\mathrm{pH} 2 \cdot 15$. The reaction of the mixture should therefore lie close to $\mathrm{pH} 2$, for if the $\mathrm{pH}$ value is higher no yellow colour appears, and if lower the blue tint gives a resultant greenish shade. The authors named recommend that comparisons should be made against picric acid to afford permanent standards, and find it convenient to make up a solution containing 36.9 mgrms. per litre of picric acid as giving a yellow corresponding to that given by 50 mgrms. of $\mathrm{SiO}_{2}$ per litre. This was diluted by the writer 
to give standards equivalent to 2.0 and 0.5 mgrms. $\mathrm{SiO}_{2}$ per litre. Comparisons were made in 100 c.c. graduated cylinders, provided with taps near the base. By this means it was possible to distinguish a faint yellow tint using the 0.5 standard at the level of 40 c.c. - or possibly 30 c.c., which corresponds to detecting $0 \cdot 2-0 \cdot 15$ mgrms. per litre of $\mathrm{SiO}_{2}$. The figures given in the second decimal place in the tables are, therefore, of uncertain significance. The use of a light blue glass was found helpful in judging these faint yellow tints. With sea-water it was necessary to concentrate the liquid by evaporating to one-fourth or one-fifth in a platinum dish, but the crystallisation of the salts is a source of trouble and prevents further concentration. Traces of silica in suspension are liable to be dissolved during the evaporation.

\section{SUMMARY.}

1. There are indications of seasonal changes in the silica in solution in fresh-water ponds, which cannot be explained by the mere dilution or concentration of the solutes in general; they appear rather to be due to the action of diatoms. A minimum value of $0.5 \mathrm{mgrms}$. of $\mathrm{SiO}_{2}$ per litre in April rose to a maximum of 1.3 in June in one pond.

2. It is also probable that the silica content of sea-water undergoes similar seasonal changes, but the fact that traces of silica from the bottles had gone into solution during storage renders this uncertain. Sea-water in June was found to contain $0 \cdot 2$ mgrm. $\mathrm{SiO}_{2}$ per litre, or somewhat less.

3. Pipe supplies were found to contain from $3 \cdot 3-6 \cdot 2$ mgrms. $\mathrm{SiO}_{2}$ per litre, lesser values found in two ponds appear to suggest the removal of silica by diatoms.

4. The walls of resistance glass vessels were found to give off no measurable amount of silica to distilled water, but boiling for three hours with sea-water increased the silica content of the latter by from $1 \cdot 5-5 \cdot 5 \mathrm{mgrms}$. per litre. Apparently the higher alkalinity of the sea-water, which is raised still further by boiling, or by photosynthesis in diatom cultures, favours the solution of the silica.

5. The method of Diénert and Wandenbulcke has been found sensitive enough to estimate silica down to a limit of $0 \cdot 2-0 \cdot 15 \mathrm{mgrms}$. per litre without concentrating the solution. The liquid under examination should, after adding the reagents, be close to $\mathrm{pH} 2$. 


\section{REFERENCES.}

Allen, E. J., and Nelson, E. W. 1910. On the artificial culture of marine plankton organisms. This Journal, 8, 421-474, and Q.J. Microscop. Sci., 1910, 55, 361-431.

Brandt, K. 1920. Über den Stoffwechsel im Meere. 3 Abhandlung. Wiss. Meeresuntersuch. Abt. Kiel, 18, 185-430.

Couprn, H. 1922. Sur l'origine de la carapace siliceuse des Diatomées. C.R. Acad. des Sciences, Paris, 1\%5, 1226-1229.

Diénert, F., and Wandenbulcke, F. 1923. Sur le dosage de la silice dans les eaux. C.R. Acad. des Sciences, Paris, 176, 1478-1480.

Lehfeldt, R. A. 1908. Electro-chemistry, London.

Murray, J., and Irvine, R. 1891. On silica and the siliceous remains of organisms in modern seas. Proc. Roy. Soc., Edinburgh, 18, 229-250.

Richter, O. 1904. Über Reinkulturen von Diatomeen und die Notwendigkeit der Kieselsäure für Nitzschia palea (Kütz.) W. Sm. Verh. d. Gesell. deut. Naturf. u. Azzte. Breslau, 2, 249.

Thresh, J. C. 1922. The action of natural waters on lead. Analyst,. Nov. and Dec., 1922.

Vernadsky, W. J. 1922. Sur le problème de la decomposition du kaolin par les organismes. C.R. Acad. des Sciences, Paris, 175, 450-452. 